\title{
3 Research Square \\ Grazing Effects on Day Butterflies in a Mediterranean Woodland Ecosystem in Northern Israel
}

Gad Ish Am ( $\sim$ ishamgadi@gmail.com )

The Israeli Lepidopterists Society https://orcid.org/0000-0002-0932-3186

\section{Talia Oron}

Israel Nature and Parks Authority

\section{Research article}

Keywords: Mediterranean woodland, biodiversity conservation, day-butterflies, cattle grazing, monophagous species, endangered species

Posted Date: November 3rd, 2020

DOI: https://doi.org/10.21203/rs.3.rs-99467/v1

License: (c) (i) This work is licensed under a Creative Commons Attribution 4.0 International License.

Read Full License 


\section{Abstract}

The effects of cattle grazing on biodiversity in Mediterranean woodlands are yet unknown. To assess these effects on diurnal butterflies, we conducted daytime surveys in the Mt. Meron nature reserve (northern Israel) in two habitats over two different years. In each habitat we chose one site that was grazed by cattle and, as a control, a similar but ungrazed site. Belt transects ( $5 \mathrm{~m}$ wide), divided for $100 \mathrm{~m}$ replications, were surveyed five times on ridges in 2015 (11 replications, 538 butterflies, 25 species), and nine times in valleys in 2016 (12 replications, 3,944 butterflies, 38 species). In both habitats, species similarity index between sites was high. Richness was higher in the ridge control and evenness was higher in the valley grazed site. In both habitats total abundance was ca. twofold higher in the control, and the abundance of woody affiliated butterflies was threefold higher in the control, probably due to overgrazing, which affects butterflies' breeding niches. For batha polyphagous and oligophagous butterfly species, abundance was similar between the sites, and for a few of those, associated with increaser plants, it was even higher in the grazed sites. However, the batha monophagous species were significantly more abundant in the control. Monophagous and endangered species were found to be more sensitive to cattle grazing. We conclude that the current cattle grazing management in Mt. Meron reserve affects butterfly populations negatively. Therefore, we recommend more regulated grazing and earlyseason deferment precautions, along with designation of no-grazing areas in reserves.

\section{Background}

In the eastern Mediterranean region, goat and sheep grazing has been practiced for about 10,000 years, and constitutes an important factor in shaping the ecosystems (Naveh and Dan 1973; Perevolotsky and Seligman 1998). During recent decades, traditional foraging by goats declined due to economic and social changes. The absence of large herbivores together with legal restrictions of wood cutting led to more closed and spatially homogeneous woody vegetation, reduced plant diversity, and increased fire risk due to the accumulation of inflammable material. To cope with these negative phenomena, many Israeli Mediterranean nature reserves have implemented managed beef-cattle grazing. Since the early 1980 s, cattle herds have been introduced into about one-third of the Mt. Meron nature reserve, our research area. To explore the effect of this new management method on the herbaceous vegetation components, a fiveyear research project was established in 79 sites in nature reserves in northern Israel, 10 out of them in woodlands on Mt. Meron (Noy-Meir et al. 1989). In most of the sites, the survey found maximum plant richness and diversity under a medium stocking rate grazing regime. However, in the Mt. Meron sites, no difference was found between cattle-grazed and ungrazed plots in terms of plant richness. Since then, as recommended, seasonal grazing has been applied with early-season deferment in some parts of the reserve (Golodets et al. 2011; Gutman et al. 1999), but year-round grazing is implemented in other parts of the reserve. The above-mentioned findings of Noy-Meir et al. (1989) have been supported by many other studies of cattle grazing in Israel (e.g., Naveh and Whittaker 1979; Perevolotsky and Seligman 1998; NoyMeir and Oron 2001), which found positive, mainly moderate, effects of grazing management on herbaceous plant richness and diversity, which supporting the intermediate disturbance hypothesis 
(Connell 1978). Some studies in Israel have researched the grazing effects on the woody components. In the same area that we examined, Carmel and Kadmon (1999) found that both cattle grazing and goat grazing reduced the rate of tree cover increase, but even intensive grazing did not halt the process. Agra and Ne'eman (2009) found that in the short term (two years), canopy removal had a positive effect, but cattle grazing negatively affected the herbaceous species richness. Glasser and Hadar (2014) concluded that grazing must be considered in the broad perspective of its effects on, and benefits to the natural ecosystem, and not only its agricultural livestock-food-supply aspect. Schoenbaum et al. (2018) found that after four consecutive annual seasons of cattle foraging, no negative effects on woody species richness could be detected, but the vine species richness and abundance decreased significantly. Kirk et al.'s (2019) study of a Mediterranean maquis in north Tunisia mountains showed that the herbaceous community composition was negatively affected by any grazing pressure, but the woody community composition was damaged only under moderate-to-high grazing pressure.

Day butterflies (Lepidoptera, Rhopalocera) are easy to observe and identify and they constitute an important link within the food web. Their short life cycle and high breeding potential enable them to respond quickly to changes in both biotic and abiotic environmental factors, such as habitat, climate, host and food plants, as well as their predators and parasites. These characteristics enable the common use of day butterflies as a bio-indicator for ecosystem status and changes (Nowicki et al. 2008; Pe'er and Settele 2008; Schwartz-Tzachor 2007).

Studies of the impact of grazing on butterfly communities have so far yielded inconsistent conclusions. In research conducted in the Carpathian Mountains, Elligsen et al. (1997) found an advantage for daybutterfly populations under moderate grazing, compared with both heavy grazing and no-grazing regimes. However, in Germany, Kruess and Tscharntke (2002) found that the highest richness, abundance, and diversity of butterfly populations was under no-grazing management, less under light grazing, and the least under heavy grazing. In their study in a nature reserve in Greece, Grill and Cleary (2003) reported a decrease of butterfly richness under grazing, compared with a no-grazing area. They also found that the endangered butterfly species was concentrated at sites with low human impact. A similar result was reported in three other European studies (Börschig et al. 2013 in Germany; Jugovic et al. 2013 in Slovenia; Schtickzella et al. 2007 in France), which also found an advantage for butterfly populations under no grazing, compared with any grazing management.

In their study of the influence of wild boar rooting activity on butterfly populations in Italy, Scandurra et al. (2016) also found higher butterfly species richness, abundance, and diversity in the no-boar area, in comparison with the boar activity area. They reported that butterfly specialist species were significantly more affected by boar activity than generalist species were. In contrast, in northern Israel (Ramat Hanadiv, Carmel Mt.), Schwartz-Tzachor (2007) found that cattle grazing in a garrigue (shrub) area increased butterfly abundance, although it had no effect on butterfly species richness or diversity. A species-specific study in Israel of the butterfly Tomares nesimachus also indicated lack of grazing (and with it, a succession progress) as a greater threat for this endangered and protected grassland species than overgrazing (Pe'er and Settele 2008). In another recent Israeli survey, butterfly abundance in a 
grassland ecosystem on the Golan Heights was found to be higher in the grazed area, and no overall differences were found in butterfly richness and diversity between grazed and ungrazed sites (Pe'er et al. 2016).

The present study aimed to assess the impacts of beef cattle grazing on butterfly communities (richness, abundance, and community structure) in Mt. Meron Nature Reserve, as representative of a northern Israeli Mediterranean mesic woodland ecosystem.

\section{Materials}

\section{Study area}

Butterfly survey was conducted during 2015 and 2016 in the Mt. Meron Nature Reserve (Upper Galilee, northern Israel, Fig. 1), which comprises about 8,000 ha. The study area is a Mediterranean woodland ecosystem, $700 \mathrm{~m}$ to $1000 \mathrm{~m}$ above sea level, with a mean annual precipitation of $900 \mathrm{~mm}$; almost all the rain falls between November and March. The rock is limestone and dolomite with thin layers of chalk and marl.

The total vegetation cover in the study area was $95 \%$, with the follow composition: (a) woody patches: composed of ca. 60\% broad-leaf trees, 8-12 m high, ever-green (mainly Quercus calliprinos) and deciduous (e.g., Quercus boissieri, and some Rosaceae Spp.), and ca. 15\% shrubs (e.g., Spartium junceum, Rhamnus punctata); and (b) batha patches: composed of ca. $10 \%$ dwarf shrubs (e.g., Sarcopoterium spinosum) and ca. 10\% herbs (about 150 species, Oron and Lavi 2017). A decrease of about $15 \%$ in the cover by wood and shrub components was reported in the areas that had been under cattle grazing for 20 years, that is, our treatment transects (GIS layer of classified vegetation formations, 2013 landsat8 satellite imagery analysis, data by Israel Nature and Parks Authority). Stocking rate in the research area was 200 adult beef cows on 400 hectares, i.e., 0.5 livestock units per hectare, which is considered a high stocking rate (Gutman et al. 2000; Schoenbaum et al. 2018). Since herbaceous component was in shortage in the woodland habitat, and the grazing management was based on woody components along the dry season, a concentrated supplement of protein-rich food was supported in the field.

Two sites were chosen for sampling each year: one had been under cattle grazing for about 20 years, and the control site was free of cattle grazing. The two sites in 2015 were located along ridges, separated by a distance of $2 \mathrm{~km}$ : The Neria site was under a winter-spring (December-May) cattle grazing regime; and the Afa'im site was free of cattle. The two sites in 2016 were located along two valleys (narrow valleys that are dry riverbeds), separated by a distance of $3 \mathrm{~km}$ : The Hiram site was under a summer-autumn (June-November) cattle grazing regime, and the Tzo'er site had been free of cattle for two years, and under light cattle grazing during the previous four decades. The other physical and biological conditions were similar for the two pairs of sites.

\section{Butterfly observations}


Alongside dirt tracks, we marked 1,100 m survey transects on ridges in 2015, and 1,200 m survey transects along valleys in 2016. These transects alternately crossed patches of wood and of batha (open vegetation). The transects were divided into sections of 100 meters each, which were considered as replications for the analysis. Butterfly transect counts were conducted according to the Pollard scheme (Pollard 1977, 1979). For each section, we recorded all the observed butterfly species and individual numbers within a 5-m belt, while walking slowly along the road (an average of 5 min per 100-m section). We walked together; the first author identified the butterflies and the co-author recorded the data. For butterfly identification, we used the Field Guide to the Butterflies of Israel (Benyamini 2010). In cases of uncertainty about a butterfly identity, it was photographed, or if necessary, captured using a net and then released at the site. Observations were conducted in appropriate weather for butterfly activity, i.e., with no rain or gusts of wind and within the temperature range of $19^{\circ}$ to $32^{\circ} \mathrm{C}$. Monitoring at the grazed and the control ungrazed sites was performed at consecutive hours of the same day, or at similar hours on consecutive days, due to weather conditions. We conducted 5 transect counts along ridges between April and September 2015, and 9 transect counts along valleys between March and July 2016.

Definition of the butterfly feeding strategy (Benyamini 2010; Tomer O. personal communication)

Monophagous species: breeding on 1 or 2 closely related plant species.

Oligophagous species: breeding on different plant species of the same family.

Polyphagous species: breeding on plant species of different families.

\section{Statistical analysis}

Statistical analysis and figs drawing were performed using Excel software.

To characterize butterfly communities and compare the different sites, we used the following indicators:

Richness: The numbers of species in the grazed and the control (ungrazed) sites, respectively, were compared separately for each year (2015 on ridges, 2016 in valleys), using a t-test for comparing replications, and a paired t-test for comparing survey transect dates.

Richness similarity index: A Jaccard similarity index (Jaccard 2012) was employed separately for each year (2015 on ridges, 2016 in valleys), to evaluate the similarity of the species lists of the two grazing regimes.

Abundance: The total numbers of individuals in the grazed and the control (ungrazed) sites were compared separately for each year (2015 on ridges, 2016 in valleys) using a t-test for comparing replications, and a paired t-test for comparing survey transect dates. The numbers of individuals of each species in the different grazing regimes were compared using a $\chi^{2}$ test.

Diversity: We used a Shannon diversity index (Shannon 1948) to examine diversity. This index is sensitive to counts of single individuals per species (mainly endangered species). The Shannon indices of the 
grazed and the control (ungrazed) sites were compared separately for each year (2015 on ridges, 2016 in valleys) using a t-test.

Evenness: A Pielou index (Pielou 1975), which is derived from the Shannon diversity index, was used to examine evenness. The evenness indices for the grazed and the control (ungrazed) sites were compared separately for each year (2015 on ridges, 2016 in valleys) using a t-test.

Abundance according to habitat and host plants: Abundance in the grazed and the control (ungrazed) sites was compared separately for each year (2015 on ridges, 2016 in valleys), according to the butterfly habitat affiliation: trees or batha patches and butterfly species host plants (Benyamini 2010).

\section{Results}

A total of 4482 individuals belonging to 36 species and 6 families (Papilionidae, Pieridae, Nymphalidae, Satyridae, Lycaenidae, and Hesperiidae) were recorded during the two research seasons.

\section{Species richness}

The mean number of species in ridges (2015) was significantly lower in the grazed site (7.5 species/section) than in the control (11.0 species/section), but no such difference was found in the valleys (2016) (Fig. 2). Maximum richness in picking season was similar in both habitats (16 species, Fig. 3). The total number of species on ridges was 22 in the grazed area and 23 in the control; in the valleys, it was 31 species in the grazed and 35 in the control areas.

\section{Species similarity}

Altogether, 39 species were recorded in the two habitats, ridges and valleys, and under the two managements: grazing and control (no grazing) (Table 4). On the ridges (2015), 20 identical species and 5 exclusive species were recorded under the two managements, with high species similarity $(80 \%$, Table 1). In the valleys (2016), 28 identical species and 10 exclusive species were recorded under the two managements, with species similarity of $78 \%$.

Table 1

Similarity of butterfly species between cattle grazing and ungrazed sites

\begin{tabular}{|llllll|}
\hline $\begin{array}{l}\text { Habitat } \\
\text { (year) }\end{array}$ & Management & $\begin{array}{l}\text { Total } \\
\text { species }\end{array}$ & $\begin{array}{l}\text { Unique } \\
\text { species }\end{array}$ & $\begin{array}{l}\text { Identical } \\
\text { species }\end{array}$ & $\begin{array}{l}\text { Jaccard } \\
\text { Index }\end{array}$ \\
\hline Ridges (2015) & Grazing & 22 & 2 & 20 & 0.80 \\
\hline & Control & 23 & 3 & & \\
\hline Valleys (2016) & Grazing & 35 & 7 & 28 & 0.78 \\
\hline & Control & 31 & 3 & & \\
\hline
\end{tabular}




\section{Abundance}

In both habitats, the mean number of individual butterflies was significantly lower in the grazed sites than in the control: $85 \%$ and $79 \%$ on ridges and in valleys, respectively (Fig. 4). Maximum abundance was recorded in mid-May in the valleys (2016), and at the beginning of June on the ridges (2015, May transect counts were not implemented) (Fig. 5). On the ridges, the total richness was 189 individuals in the grazed site and 349 in the control; in the valleys, it was 1,415 individuals in the grazed site and 2,529 individuals in the control. Less individuals were recorded in the grazed sites than in the control in all transect counts, in both habitats (Fig. 5).

\section{Evenness (Pielou index)}

A relatively high mean of species evenness was found on the ridges (2015), which was similar between the two managements. A lower mean of species evenness was recorded in the valleys (2016), which was significantly higher in the grazed site than in the control (Table 2).

Table 2

Mean species evenness (Pielou index) of butterfly populations in the grazed and the control sites

\begin{tabular}{|lllll|}
\hline Habitat & Management & \multicolumn{3}{l|}{ Species evenness } \\
\cline { 3 - 5 } (year) & & Mean & S.D. & Significance \\
\hline Ridges (2015) & Grazing & 0.89 & 0.045 & 0.68 \\
\hline & Control & 0.90 & 0.045 & \\
\hline Valleys (2016) & Grazing & 0.81 & 0.047 & $<0.001$ * \\
\hline & Control & 0.71 & 0.082 & \\
\hline * Significant difference $(p<0.05$, t-test $)$ & & \\
\hline
\end{tabular}

\section{Diversity (Shannon index)}

The mean diversity of butterfly populations was lower in the grazed site than in the control on ridges, but higher in the grazed site than in the control in valleys (Table 3). 
Table 3

Mean diversity (Shannon index) of butterfly populations of grazed and control sites

\begin{tabular}{|lllll|}
\hline \multirow{2}{*}{$\begin{array}{l}\text { Habitat } \\
\text { (year) }\end{array}$} & Management & \multicolumn{3}{l|}{ Shannon diversity } \\
\cline { 3 - 5 } Ridges (2015) & Grazing & 1.75 & 0.32 & $0.0086^{*}$ \\
\hline & Control & 2.14 & 0.31 & \\
\hline Valleys (2016) & Grazing & 2.30 & 0.19 & $0.0093 *$ \\
\hline & Control & 2.05 & 0.24 & \\
\hline * Significant difference $(p<0.05$, t-test $)$ & & \\
\hline
\end{tabular}

\section{Abundance according to habitat and host plants}

Twenty-five of the 39 observed butterfly species are exclusively (or mainly) active and lay eggs in batha patches, and only 10 are mainly active in wood patches (Benyamini 2010). The other four species are not exclusively connected to a specific habitat (Table 4). 
Table 4

List of recorded butterfly species and selected characteristics

\begin{tabular}{|c|c|c|c|c|c|c|}
\hline \multirow{3}{*}{$\begin{array}{l}\text { Plant formation } \\
\text { and } \\
\text { butterfly species }\end{array}$} & \multicolumn{4}{|c|}{ Number of individuals } & \multirow{3}{*}{$\begin{array}{l}\text { Feeding } \\
\text { strategy }\end{array}$} & \multirow[t]{3}{*}{ Host plants } \\
\hline & \multicolumn{2}{|c|}{ Ridges(2015) } & \multicolumn{2}{|c|}{ Valleys(2016) } & & \\
\hline & G & C & G & C & & \\
\hline \multicolumn{7}{|l|}{ Batha patches } \\
\hline Papilio machaon & 0 & 0 & 0 & 1 & $\mathrm{P}$ & $\begin{array}{l}\text { Apiaceae-few species, Ruta } \\
\text { chalepensis }\end{array}$ \\
\hline Pieris brassicae & 6 & 6 & 113 & 151 & $\mathrm{P}$ & $\begin{array}{l}\text { Brassicaceae species, Capparis } \\
\text { spp. And more }\end{array}$ \\
\hline Artogeia rapae & 3 & 6 & 13 & 10 & $\mathrm{P}$ & $\begin{array}{l}\text { Brassicaceae species, Capparis } \\
\text { spp. And more }\end{array}$ \\
\hline Pontia daplidice & 11 & 7 & 87 & $17^{\star}$ & $\mathrm{P}$ & $\begin{array}{l}\text { Brassicaceae species, Reseda } \\
\text { spp. And more }\end{array}$ \\
\hline $\begin{array}{l}\text { Anthocharis } \\
\text { cardamines }\end{array}$ & 0 & 0 & 10 & 4 & 0 & Brassicaceae species \\
\hline $\begin{array}{l}\text { Anthocharis } \\
\text { damone En }\end{array}$ & 0 & 0 & 1 & 0 & 0 & $\begin{array}{l}\text { Isatis lusitanica, } \\
\text { Crambe hispanica (?) }\end{array}$ \\
\hline Colias croceus & 54 & $27^{*}$ & 173 & $46^{*}$ & 0 & Fabaceae species \\
\hline Vanessa cardui & 6 & 2 & 51 & 52 & $\mathrm{P}$ & Many species of different families \\
\hline Melitaea telona & 1 & 2 & 11 & 5 & $\mathrm{P}$ & $\begin{array}{l}\text { Species of Asteraceae, Dipsaceae } \\
\text { and more }\end{array}$ \\
\hline Melitaea syriaca & 0 & 0 & 0 & $7 *$ & 0 & Vebascum spp., Scrophularia spp. \\
\hline Melanargia titea & 0 & $6 *$ & 0 & 1 & 0 & Poaceae species \\
\hline $\begin{array}{l}\text { Lasiommata } \\
\text { maera }\end{array}$ & 0 & 3 & 12 & 12 & 0 & Poaceae species (mainly) \\
\hline Cigaritis acamas & 1 & 0 & 2 & $49 *$ & M & Cooperation with ants \\
\hline 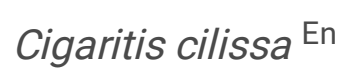 & 2 & 1 & 62 & $209 *$ & M & Cooperation with ants \\
\hline
\end{tabular}

$G$ grazed site, $C$ control (ungrazed) site, $P$ Polyphagous species, $O$ Oligophagous species, $M$ Monophagous species

En Endangered butterfly species in Israel (Pe'er and Benyamini 2008)

a No discrimination was accomplished between the two similar species, Zerynthia deyrollei and Zerynthia cerisyl, which are common in the research area

*Significant difference between managements within the habitat $\left(p<0.05, \chi^{2}\right.$ test $)$ 


\begin{tabular}{|c|c|c|c|c|c|c|}
\hline \multirow{3}{*}{$\begin{array}{l}\text { Plant formation } \\
\text { and } \\
\text { butterfly species }\end{array}$} & \multicolumn{4}{|c|}{ Number of individuals } & \multirow{3}{*}{$\begin{array}{l}\text { Feeding } \\
\text { strategy }\end{array}$} & \multirow[t]{3}{*}{ Host plants } \\
\hline & \multicolumn{2}{|c|}{ Ridges(2015) } & \multicolumn{2}{|c|}{ Valleys(2016) } & & \\
\hline & G & C & G & C & & \\
\hline Lycaena phlaeas & 1 & 2 & 3 & 2 & 0 & Polygonum spp. \\
\hline $\begin{array}{l}\text { Lycaena } \\
\text { thersamon }\end{array}$ & 1 & 0 & 2 & 0 & 0 & Polygonum spp. \\
\hline $\begin{array}{l}\text { Lampides } \\
\text { boeticus }\end{array}$ & 14 & 27 & 102 & $179 *$ & $\mathrm{P}$ & $\begin{array}{l}\text { Fabaceae species, Capparis spp. } \\
\text { And more }\end{array}$ \\
\hline Aricia agestis En & 0 & 0 & 57 & $8^{*}$ & 0 & Geraniaceae species \\
\hline Cyaniris bellis En & 0 & 0 & 4 & 3 & 0 & $\begin{array}{l}\text { Trifolium spp. And other } \\
\text { Fabaceae species }\end{array}$ \\
\hline $\begin{array}{l}\text { Polyommatus } \\
\text { Icarus }\end{array}$ & 2 & 8 & 41 & $9 *$ & 0 & Fabaceae species \\
\hline $\begin{array}{l}\text { Pseudophilotes } \\
\text { vicrama }\end{array}$ & 3 & $18^{\star}$ & 3 & 3 & $\mathrm{P}$ & $\begin{array}{l}\text { Lamiaceae, Rosaceae, } \\
\text { Convolvulaceae species and more }\end{array}$ \\
\hline $\begin{array}{l}\text { Glaucopsyche } \\
\text { alexis En }\end{array}$ & 0 & 0 & 0 & $27^{*}$ & 0 & Fabaceae species \\
\hline $\begin{array}{l}\text { Carcharodus } \\
\text { alceae }\end{array}$ & 0 & 0 & 0 & 4 & 0 & Malvaceae species \\
\hline $\begin{array}{l}\text { Muschampia } \\
\text { teessalum }\end{array}$ & 0 & 0 & 0 & $23^{*}$ & M & Phlomis spp. \\
\hline Thymelicus hyrax & 0 & 0 & 0 & 2 & 0 & $\begin{array}{l}\text { Hordeum bulbosum and other } \\
\text { Poaceae spp. }\end{array}$ \\
\hline \multicolumn{7}{|l|}{ Wood patches } \\
\hline Zerynthia spp. ${ }^{\mathrm{a}}$ & 9 & 15 & 36 & 20 & M & Aristolochia spp. \\
\hline $\begin{array}{l}\text { Gonepteryx } \\
\text { Cleopatra }\end{array}$ & 3 & $48^{*}$ & 78 & $215^{\star}$ & M & Rhamnus spp. \\
\hline Limenitis reducta & 8 & $24^{\star}$ & 57 & $164^{\star}$ & $M$ & Lonicera spp. \\
\hline
\end{tabular}

$G$ grazed site, $C$ control (ungrazed) site, $P$ Polyphagous species, $O$ Oligophagous species, $M$ Monophagous species

En Endangered butterfly species in Israel (Pe'er and Benyamini 2008)

a No discrimination was accomplished between the two similar species, Zerynthia deyrollei and Zerynthia cerisyl, which are common in the research area

*Significant difference between managements within the habitat $\left(p<0.05, \chi^{2}\right.$ test) 


\begin{tabular}{|c|c|c|c|c|c|c|}
\hline \multirow{3}{*}{$\begin{array}{l}\text { Plant formation } \\
\text { and } \\
\text { butterfly species }\end{array}$} & \multicolumn{4}{|c|}{ Number of individuals } & \multirow{3}{*}{$\begin{array}{l}\text { Feeding } \\
\text { strategy }\end{array}$} & \multirow[t]{3}{*}{ Host plants } \\
\hline & \multicolumn{2}{|c|}{ Ridges(2015) } & \multicolumn{2}{|c|}{ Valleys(2016) } & & \\
\hline & G & C & G & C & & \\
\hline Hipparchia fatua & 1 & 4 & 2 & 1 & 0 & $\begin{array}{l}\text { Piptatherum spp. And more } \\
\text { Poaceae species }\end{array}$ \\
\hline $\begin{array}{l}\text { Maniola } \\
\text { telmessia }\end{array}$ & 14 & $47^{*}$ & 406 & $1060^{\star}$ & 0 & Poaceae species \\
\hline Kirinia roxelana En & 5 & 7 & 3 & 5 & 0 & Poaceae species \\
\hline Satyrium spini & 2 & $16^{*}$ & 57 & $164^{\star}$ & M & Rhamnus spp. \\
\hline Satyrium ilicis & 19 & 32 & 3 & $17^{\star}$ & M & Quercus calliprinos \\
\hline Callophrys rubi En & 0 & 0 & 1 & 0 & M & Rhamnus punctata \\
\hline $\begin{array}{l}\text { Celastrina } \\
\text { argiolus En }\end{array}$ & 0 & 0 & 1 & 5 & $\mathrm{P}$ & $\begin{array}{l}\text { Cooperation with ants, Several } \\
\text { families }\end{array}$ \\
\hline \multicolumn{7}{|l|}{ Unspecified habitat } \\
\hline Vanessa atalanta & 0 & 2 & 0 & 0 & 0 & Urticaceae species \\
\hline $\begin{array}{l}\text { Lasiommata } \\
\text { megera }\end{array}$ & 23 & 39 & 14 & $42^{\star}$ & 0 & Poaceae species \\
\hline Leptotes pirithous & 0 & 0 & 1 & 4 & $\mathrm{P}$ & $\begin{array}{l}\text { Fabaceae species and other } \\
\text { families }\end{array}$ \\
\hline Spialia orbifer & 0 & 0 & 9 & 8 & 0 & $\begin{array}{l}\text { Rubus spp. And other Rosaceae } \\
\text { species }\end{array}$ \\
\hline \multicolumn{7}{|c|}{$\begin{array}{l}G \text { grazed site, } C \text { control (ungrazed) site, } P \text { Polyphagous species, } O \text { Oligophagous species, } M \\
\text { Monophagous species }\end{array}$} \\
\hline \multicolumn{7}{|c|}{ En Endangered butterfly species in Israel (Pe'er and Benyamini 2008) } \\
\hline \multicolumn{7}{|c|}{$\begin{array}{l}\text { a No discrimination was accomplished between the two similar species, Zerynthia deyrollei and } \\
\text { Zerynthia cerisyl, which are common in the research area }\end{array}$} \\
\hline *Significant differe & $h$ & en man & eme & within & e habita & $<0.05, \chi^{2}$ test) \\
\hline
\end{tabular}

\section{Abundance of the wood affiliated species}

In both habitats (ridges and valleys), the abundance of the wood-affiliated butterfly species was significantly lower in the grazed sites than in the control (one-third to one-half of the individuals, Tables 5 , $6)$. 


\section{Abundance of the batha-affiliated species}

Abundance of the batha-affiliated butterfly species was lower in the grazing site than in the control on ridges, and similar between managements in valleys (Tables 5, 6). Abundance was lower under grazing than in the ungrazed control on ridges for the butterfly species that are associated with Brassicaceae, Poaceae, and Lamiaceae plants, and in valleys only for the butterflies associated with the Lamiaceae species.

Table 5

Butterfly abundance by plant formation and host plants on ridges (2015)

\begin{tabular}{|lllll|}
\hline $\begin{array}{l}\text { Plant } \\
\text { formation }\end{array}$ & $\begin{array}{l}\text { Number } \\
\text { of }\end{array}$ & $\begin{array}{l}\text { Number of individuals in the } \\
\text { grazed site }\end{array}$ & $\begin{array}{l}\text { Number of individuals in } \\
\text { the control }\end{array}$ & $p\left(\chi^{2}\right)$ \\
\hline Batha patches & & & & \\
\hline $\begin{array}{l}\text { Brassicaceae } \\
\text { (mainly) }\end{array}$ & 3 & 17 & 58 & $0.001^{*}$ \\
\hline Poaceae & 2 & 0 & 5 & 0.068 \\
\hline Lamiaceae & 1 & 5 & 15 & 0.10 \\
\hline $\begin{array}{l}\text { Fabaceae } \\
\text { (mainly) }\end{array}$ & 3 & 60 & 58 & 0.90 \\
\hline Other families & 5 & 8 & 8 & 1.00 \\
\hline Total & 14 & 90 & 145 & $0.011^{*}$ \\
\hline Wood patches & & & & $0.001^{*}$ \\
\hline Poaceae & 3 & 14 & 58 & 0.052 \\
\hline Trees & 4 & 73 & 110 & 0.11 \\
\hline Vines & 2 & 17 & 33 & $0.001^{*}$ \\
\hline Total & 9 & 104 & 201 & \\
\hline * Significant difference $\left(p<0.05, \chi^{2}\right.$ test $)$ & & & \\
\hline
\end{tabular}


Table 6

Butterfly abundance, by plant formation and host plants in valleys (2016)

\begin{tabular}{|c|c|c|c|c|}
\hline $\begin{array}{l}\text { Plant } \\
\text { formation } \\
\text { and host plants }\end{array}$ & $\begin{array}{l}\text { Number } \\
\text { of } \\
\text { species }\end{array}$ & $\begin{array}{l}\text { Number of individuals in the } \\
\text { grazed site }\end{array}$ & $\begin{array}{l}\text { Number of individuals in } \\
\text { the control }\end{array}$ & $p\left(x^{2}\right)$ \\
\hline \multicolumn{5}{|l|}{ Batha patches } \\
\hline $\begin{array}{l}\text { Brassicaceae } \\
\text { (mainly) }\end{array}$ & 5 & 244 & 182 & 0.33 \\
\hline Poaceae & 3 & 12 & 15 & 0.68 \\
\hline Lamiaceae & 2 & 3 & 26 & $0.001 *$ \\
\hline $\begin{array}{l}\text { Fabaceae } \\
\text { (mainly) }\end{array}$ & 5 & 320 & 264 & 0.10 \\
\hline Other families & 8 & 124 & 79 & $0.025^{\star}$ \\
\hline Total & 23 & 683 & 566 & $0.019 *$ \\
\hline \multicolumn{5}{|l|}{ Wood patches } \\
\hline Poaceae & 3 & 411 & 1,066 & $<.001 *$ \\
\hline Trees & 4 & 139 & 396 & $<.001 *$ \\
\hline Vines & 2 & 93 & 184 & $<.001 *$ \\
\hline Total & 9 & 643 & 1,646 & $<.001 *$ \\
\hline
\end{tabular}

\section{Butterfly richness and abundance by feeding strategy}

In both habitats (ridges and valleys), the abundance was significantly lower in the grazed site relative to the control for only $17 \%$ of the oligophagous and polyphagous butterfly species, and for some of these species it was actually higher in the grazing site (Table 7, Fig. 6). However, for monophagous butterflies, we found a stronger influence of cattle grazing. For $43 \%$ and $67 \%$ of these species on ridges and in valleys, respectively, lower abundance was found in the grazed sites, and the opposite effect (higher abundance in the grazed sites) was not found in any of them.

Eight endangered butterfly species were recorded in the valleys, and only two on the ridges. Six of these are monophagous or oligophagous (Table 4). 
Table 7

Changes in butterfly abundance by feeding strategy

Polyphagous and oligophagous species

Monophagous species

\begin{tabular}{|lllllll|} 
Habitat & $\begin{array}{l}\text { Total } \\
\text { number } \\
\text { of } \\
\text { species }\end{array}$ & $\begin{array}{l}\text { No. of species } \\
\text { with lower } \\
\text { abundance } \\
\text { under grazing }\end{array}$ & $\begin{array}{l}\text { No. of species } \\
\text { with higher } \\
\text { abundance } \\
\text { under grazing }\end{array}$ & $\begin{array}{l}\text { Total } \\
\text { number } \\
\text { of } \\
\text { species }\end{array}$ & $\begin{array}{l}\text { No. of } \\
\text { species with } \\
\text { lower } \\
\text { abundance } \\
\text { under grazing }\end{array}$ & $\begin{array}{l}\text { No. of species } \\
\text { with higher } \\
\text { abundance } \\
\text { under grazing }\end{array}$ \\
\hline Ridges & 18 & 3 & 1 & 7 & 3 & 0 \\
Valleys & 29 & 5 & 4 & 9 & 6 & 0 \\
\hline
\end{tabular}

\section{Discussion}

We found in two habitats, ridges (2015) and valleys (2016), in a Mediterranean mesic woodland ecosystem (Mt. Meron, Upper Galilee, northern Israel) evidence of lower day-butterfly-population indices (richness and abundance) in sites under cattle grazing, compared with ungrazed control sites. This is consistent with other studies that found a negative impact of grazing on butterfly communities (Börschig et al. 2013; Grill and Cleary 2003; Jugovic et al. 2013; Kruess and Tscharntke 2002; Schtickzella et al. 2007).

We found the woody-niche-affiliated butterflies to be more severely affected by grazing, in comparison with batha-patch-affiliated butterflies. This could be due to heavy cattle grazing on shrubs, vines (Schoenbaum et al. 2018), lower tree canopies and the understory Poaceae (grasses) plants, which are hosts for butterfly breeding (Schtickzella et al. 2007). The heavy grazing in the woods might be due to a lack of herbaceous pasture in the batha patches during the long Mediterranean dry season. This effect is supported by the findings of Kirk et al. (2019) in northern Tunisia, which showed severe damage to the woody community composition under moderate-to-high grazing pressure.

In the batha patches we found in the grazed sites (mainly on ridges), a lower abundance of butterfly species that breed on Brassicaceae, Lamiaceae and Poaceae (Tables 5,6). This can be explained by damage incurred by cattle grazing to both nectar and breeding plants of Lamiaceae and Poaceae (Schtickzella et al. 2007). It is possible that some of the Asteraceae and the Fabaceae nectar and breeding plants (and, in valleys, Brassicaceae, as well) did not significantly suffer from grazing. These plants are the hosts of generalist (polyphagous) butterfly species, mainly the Pieridae (Tables 4, 7), which did not show decline in the grazing sites, and some that even increased (Tables 5, 6, 7, Fig. 6). The moderate damage for batha-patch-affiliated butterflies due to grazing corroborates previous studies from batha Mediterranean grassland ecosystems, which reported a diversity increase under a moderate grazing regime (Noy-Meir et al. 1989).

We conclude that monophagous and endangered butterfly species are more sensitive to cattle grazing than the oligophagous and polyphagous species are (Tables 4, 7). Similar findings have been reported 
from Morocco (Thomas and Mallorie 1985), Greece (Grill and Cleary 2003), and Italy (Scandurra et al. 2016). This may be the result of big mammals' influence on the vegetation, which increases evenness (less available ecological niches) and mainly damages the more specialist and sensitive butterfly species.

The oligophagous species Aricia agestis was the only endangered species whose population was significantly larger in the grazed site than in the control site - 57 versus 8 individuals in the valleys, respectively (Table 4, Fig. 6). This butterfly breeds on plant species of the Geraniaceae, which are palatable for cattle (personal knowledge). Geraniaceae were observed in the study area only as a minor vegetation feature and could not explain that intriguing effect. This warrants further research.

The common batha-patch polyphagous species Lampides boeticus, which was negatively affected by grazing, behaved almost "monophagously" in our study area. It breeds mainly on young branches of Spartium junceum (a bush, Fabaceae), which is eaten rapidly by the cattle.

We found heavier grazing damage on the ridges in 2015 (under winter-spring grazing regime) than in the valleys in 2016 (under summer-autumn grazing regime), in terms of both butterfly richness index (Figs. 1, 2, 5), and the abundance of the batha-affiliated butterfly species. On the ridge even butterfly populations that breed on increaser plants, which may benefit from grazing, still had lower indices than in the control. However, in the valleys some of these species had higher indices in the grazed sites (see also Briske 1996). Butterfly populations that breed on Brassicaceae were lower in the grazed site on the ridges, but did not decline, and were even higher in the valleys (Tables 5,6). The same applies to Zerynthia spp. populations, which breed on the poisonous genera Aristolochia. The heavier grazing damage on the ridges, under a winter-spring grazing regime, could be attributed to that more intense management, compared with the valley grazing management of summer-autumn, with early season deferment.

The above difference between the ridges and the valleys habitats might explain the different effect there of cattle grazing on butterfly population evenness (Table 2) and diversity (Table 3). On the ridges we found high and similar evenness for the two managements, but greater diversity in the control. However, in the valleys we recorded in the control lower values of both diversity and evenness, and the evenness was there even lower than on the ridges. This lower evenness resulted from the higher number of endangered butterfly species there, most of which consist of very small populations (Table 4). The higher diversity of the control butterfly population on the ridges, compared with the grazing site, was a result of the control's higher richness combined with a similar evenness under the two managements.

Nevertheless, in the valleys, the lower control's diversity resulted from a similar mean richness in the two sites but a lower evenness in the control. This is since Shannon diversity index is positively correlated with both evenness and richness indices.

We suggest that the significant changes in the butterfly populations under cattle grazing in the Mt. Meron region can be attributed to changes caused by grazing to their host and nectar plants (Pe'er and Settele 2008; Thomas and Mallorie 1985; Schtickzella et al. 2007). This is supported by the findings of a concomitant study done on the effect of cattle grazing on the herbs' communities (Oron and Lavi 2017), 
which was carried out on the same transect lines and years. In this research the herbaceous species richness was found to be lower in the grazed sites compared with the control; species diversity indices were lower under heavy winter-spring grazing management, compared with the less severe summerautumn grazing regime; and the occurrence frequencies of the plant functional groups was found to differ clearly by management regime. All these changes would be expected to influence some of the butterfly populations. Another concomitant study, on the fungi in the woody patches of the same transects (Perelberg et al. 2016), also found a significant decrease in most of the ecological factors, which may emphasize the deep negative effect of cattle grazing on our research region.

The significantly lower butterfly population indices in the grazed sites, and almost total disappearance of the endangered species, under both heavy winter-spring grazing regime (on the ridges) and more moderate summer-autumn grazing (in the valleys), are consistent with Scandurra et al. (2016) and Schtickzella et al. (2007). However, other studies have reported significant advantages for butterflies under extensive grazing management compared with a no-grazing regime (Bartoňová et al. 2017; Munguira et al. 2017; Slancarova et al. 2015; Stefanescu et al. 2011). These contradicting findings might result from the ambiguity of the definition of "light-medium grazing management." Differences could also stem from the changing balance between the contradicting influences of grazing on plants and butterfly populations. Light-to-medium grazing may open the vegetation complex for more plant species (increase richness and diversity), but at the same time can damage or eliminate plant species of the butterflies' nectar and food complex.

The present research results demonstrate that cattle grazing, as conducted for two decades in the woodland ecosystem in northern Israel, has had significant harmful effects on the butterfly populations, apparently as a result of decreasing the habitat heterogeneity and reducing the food resources, and specifically by impairing plants. We hypothesized that in contrast to thousands of years of traditional goat grazing, the new cattle introduction in this area poses the potential for overgrazing damage. Further research is needed to support this assumption.

\section{Conclusions}

We conclude that overgrazing by beef cattle occurs in the woodland ecosystem of the Mt. Meron Nature Reserve, including the more moderate grazing regime areas in the reserve. This grazing management significantly reduces most butterfly species populations, and specifically the wood-breeding species. Most alarming are the effects on monophagous and endangered butterfly species. We suggest that this degradation in the condition of butterfly populations is a result of deterioration of their host and nectar plant populations. Far more regulated grazing management and early-season grazing deferment might mollify the damage of the cattle grazing to this ecosystem. Closed refuge areas of the nature reserve, with no grazing, are essential for protecting the endangered butterfly species.

\section{Abbreviations}


$G$ grazed site

$C$ control (ungrazed) site

P Polyphagous species

O Oligophagous species

$M$ Monophagous species

En Endangered butterfly species in Israel

\section{Declarations}

\section{Ethics approval -}

Not applicable (the research involved only monitoring existing butterfly population without any manipulation).

\section{Consent for publication -}

Not applicable (the research did not involve Human subjects).

\section{Availability of data and material -}

The datasets used and/or analysed during the current study are available from the corresponding author on reasonable request.

\section{Competing interests -}

The authors declare that have no competing interest.

\section{Funding -}

The research was fully funded by the Nature and Park Authority of Israel.

\section{Authors contribution -}

Both authors contributed equally to the research: both were involved in monitoring, in collecting data, in analyzing data and in actual writing the paper.

\section{Acknowledgements -}

We are grateful to Guy Pe'er for his valuable professional manuscript revision, and to Jonathan Saferstein for the language revision. 


\section{References}

1. Agra H, Ne'eman G (2009) Woody species as landscape modulators: Their effect on the herbaceous plants in a Mediterranean Maquis, on Mt. Meron, Israel. Forest: Journal of Forests, Woodlands and Environment 11:20-27 (in Hebrew, with English abstract)

2. Bartoňová A, Kolář V, Marešová J et al (2017) Isolated Asian steppe element in the Balkans: Habitats of Proterebia afra (Lepidoptera: Nymphalidae: Satyrinae) and associated butterfly communities. J Insect Conserv 21:559-571. doi:10.1007/s10841-017-9995-x

3. Benyamini D (2010. Revised Edition) A field guide to the butterflies of Israel. Keter, Jerusalem (In Hebrew)

4. Börschig C, Klein AM, Wehrden H von, Krauss J (2013) Traits of butterfly communities change from specialist to generalist characteristics with increasing land intensity. Basic and Applied Ecology 14:547-554

5. Briske DD (1996) Strategies of plant survival in grazed systems: A functional interpretation. Ecology and Management of Grazing Systems 37-67

6. Connell JH (1978) Diversity in tropical rain forests and coral reefs. Science, New Series, 199 (4335):1302-13010

7. Elligsen H, Beinlich B, Blachter H (1997) Effects of large-scale cattle grazing on populations of Coenonympha glycerion and Lasiommata megera (Lepidoptera: Satyridae). J of Insect Conservation 1:13-23

8. Glasser TA, Hadar A (2014) Grazing management aimed at producing landscape mosaics to restore and enhance biodiversity in Mediterranean ecosystems. Options Mediterraneenes, A, 109:437-452

9. Golodets C, Kigel J, Sternberg M (2011) Plant diversity partitioning in grazed Mediterranean grassland at multiple spatial and temporal scales. J App Ecol 48:1260-1268

10. Grill A and Cleary DFR (2013) Diversity patterns in butterfly communities of the Greek nature reserve Dadia. Biological Conservation 114:427-436

11. Gutman M, Perevolotsky A, Ungar ED, Sternberg M, Kigel J (1999) Mediterranean herbaceous vegetation response to high animal density and grazing deferment: Implications for management and conservation. In: Etienne M (ed) Dynamics and sustainability of Mediterranean pastoral systems. Zaragoza, CIHEAM, pp161-164 (Cahiers Options Méditerranéennes; n. 39)

12. Gutman, M., Henkin, Z., Holzer, Z. et al. (2000). A case study of beef-cattle grazing in a Mediterranean-type woodland. Agroforestry Systems 48(2):119-140

13. Jaccard, Paul (1912) The distribution of the flora in the alpine zone. New Phytologist. doi:10.1111/j.1469-8137.1912.tb05611.x

14. Jugovic J, Crane M, Pecnikar ZF (2013) The impact of grazing, overgrowth and mowing on spring butterfly (Lepidoptera: Rhopalocera) assemblage on dry karst meadows and pastors. Nat. Croat. 22(1):157-169 
15. Kirk DA, Hebert K, Goldsmith FB (2019) Grazing effect on woody and herbaceous plant biodiversity on a limestone mountain in northern Tunisia. Peer J 7:e7296 http://doi.org/10.7717/peerj.7296

16. Koniak G, Noy-Meir I (2009) A hierarchical, multiscale management- responsive model of Mediterranean vegetation dynamics. Ecol Modelling 220:1148- 1158

17. Kruess A, Tscharntke T (2002) Grazing intensity and the diversity of grasshoppers, butterflies, and trap-nesting bees and wasps. Conser Biol 16:1570-1580

18. Munguira M.L, Barea-Azcón JM, Castro-Cobo S, et al (2017) Ecology and recovery plans for the four Spanish endangered endemic butterfly species. J Insect Conserv. doi:10.1007/s10841-016-9949-8

19. Naveh Z, Dan J (1973) The human degradation of Mediterranean landscapes in Israel. In: Di Castri F, and Mooney HA (eds) Mediterranean-type ecosystems: Origin and structure, Ecological Studies, Vol. 7. Springer-Verlag, Berlin, pp 373-390

20. Naveh Z, Whittaker RH (1980) Structural and floristic diversity of shrublands and woodlands in Northern Israel and other Mediterranean areas. Vegetatio. https://doi.org/10.1007/BF00052445

21. Nowicki P, Settele J, Henry PY, Woyciechowski M (2008) Butterfly monitoring methods: The ideal and the real world. Israel J Ecol Evol 54(1):69-88

22. Noy-Meir I, Gutman M, Kaplan D (1989) Responses of Mediterranean grassland plants to grazing and protection. J Ecol 77:290-310

23. Noy-Meir I, Oron T (2001) Effects of grazing on geophytes in Mediterranean vegetation. J Vegetation Sci 12:749-760

24. Oron T, Lavi R (2017) The effect of cattle grazing in the Mediterranean forest in the Mt. Meron Nature Reserve on the herbaceous flora in forest clearings. Kalanit - Israel Plant Magazin (Online journal, in Hebrew) http://www.kalanit.org.il/meron-grazing/. English abstract http://www.kalanit.org.il/september-2017/

25. Pe'er G, Benyamini D (2008) The template for publishing the "conservation chain" from problem identification to practical action, exemplified through the campaign for butterfly protection in Israel. Israel J Ecol Evol 54:19-39

26. Pe'er G, Settele J (2008) The rare butterfly Tomares nesimachus (Lycaenidae) as a bioindicator for pollination services and ecosystem functioning in northern Israel. Israel J Ecol Evol 54:111-136

27. Pe'er G, Pe'er I, Shaked A (2016) Yehudiya butterfly survey report. Prepared for the Israel Nature and Parks Authority (In Hebrew)

28. Perelberg A, Gal B, Ur Y \& Oron T (2016) Effects of cattle grazing on Basidiomycotina and Ascomycotina fungi in a Mediterranean woodland ecosystem in the upper Galilee, northern Israel. A survey report. Prepared for the Israel Nature and Parks Authority (In Hebrew)

29. Perevolotsky A, Seligman NG (1998) Role of grazing in Mediterranean rangeland ecosystems. Inversion of a paradigm. BioScience 48:1007-1017

30. Pielou EC 1975. Ecological diversity. Wiley, New York 
31. Pollard E (1977) A method for assessing changes in the abundance of butterflies. Biol Conserv 12:115-134

32. Pollard E (1979) Population ecology and change in range of the white admiral butterfly Ladoga camilla in England. Ecol Entomol 4:61-74

33. Scandurra A, Magliozzi L, Fulgione D, Aria M, D' Aniello B (2016) Lepidoptera Papilionoidea communities as a sentinel of biodiversity threat: the case of wild boar rooting in a Mediterranean habitat. J Insect Conser 20:353-362

34. Schoenbaum I, Henkin Z, Yehuda Y, Voet H, Kigel J (2018) Cattle foraging in Mediterranean oak woodlands - Effects of management practices on the woody vegetation. Forest Ecol Manag. 419420:160-169

35. Schtickzella N, Turlure C, Baguette M (2007) Grazing management impact on the viability threatened bog fritillary butterfly Proclossiana Eunomia. Biol Conser 136:651-660

36. Schwartz-Tzachor R (2007) Multy-factorial analysis of a butterfly community used as a bioindicator for antropogenic activity and habitat quality in Ramat Hanadiv Nature Park. Dissertation, Haifa University (In Hebrew)

37. Shannon, C. E. (1948) A mathematical theory of communication. Bell System Technical Journal 27:379-423 and 623-656

38. Slancarova J, Garcia-Pereira P, Fric ZF, et al (2015) Butterflies in Portuguese 'montados':

Relationships between climate, land use and life-history traits. J Insect Conserv. doi:10.1007/s10841015-9801-6

39. Stefanescu, C., Torre, I., Jubany, J. et al. (2011) Recent trends in butterfly populations from north-east Spain and Andorra in the light of habitat and climate change. $J$ Insect Conserv.

https://doi.org/10.1007/s10841-010-9325-z

40. Thomas C D and Mallorie H C (1985) Rarity, species richness and conservation: Butterflies of the Atlas Mountains in Morocco. Biological Conservation 33:95-117

\section{Figures}



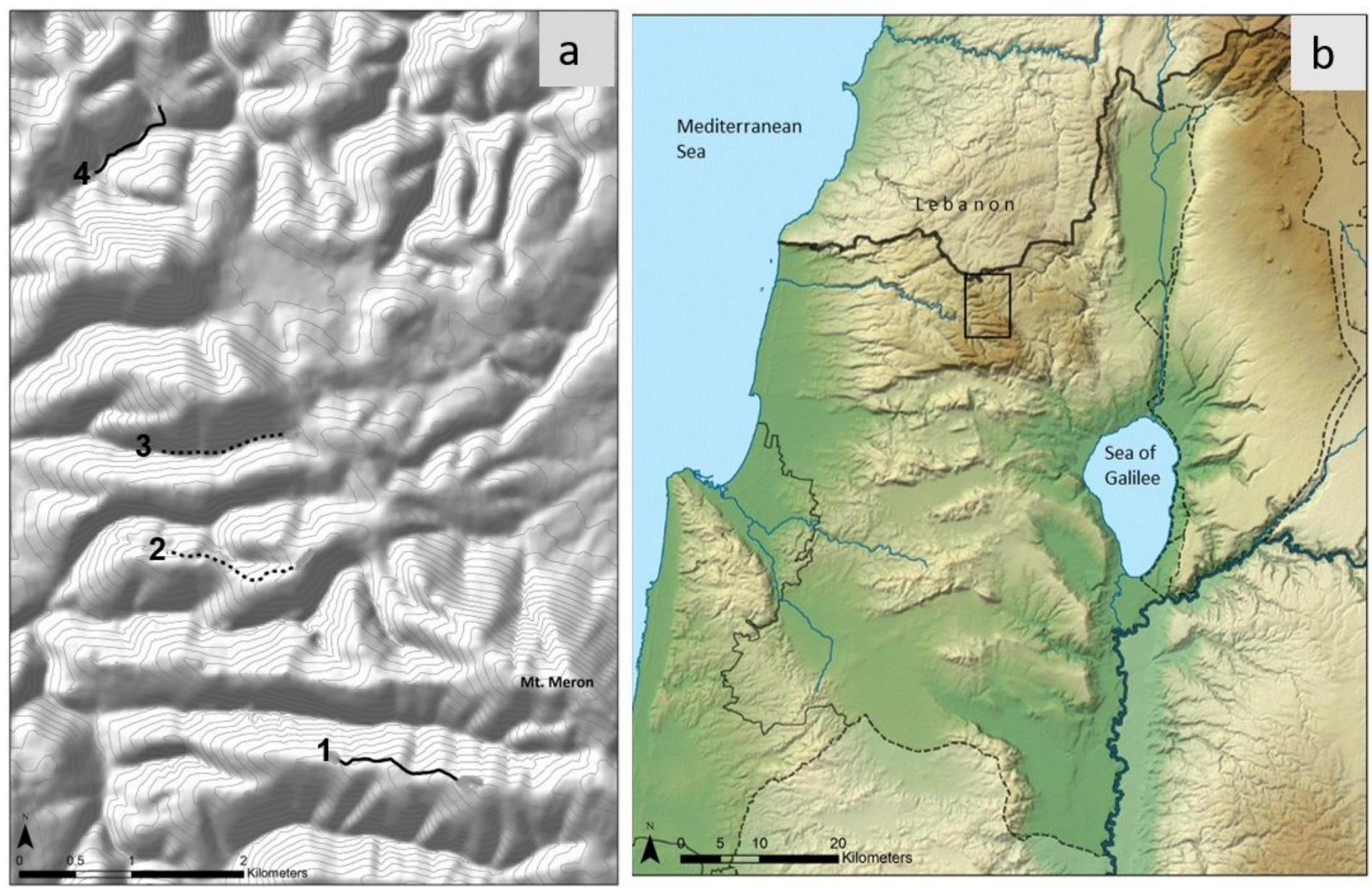

Figure 1

Topographic map of the four study transects in Mt. Meron Nature Reserve (a) and location within northern Israel (b, inset). 1) Afa'im Ridge, control, 2015; 2) Neria Ridge, grazed, 2015; 3) Hiram valley, grazed, 2016; 4) Tzo'er valley, control, 2016 Fig1a: Esri. "Topographic" [basemap]. Scale not given. "World Topographic Map". July 27, 2020. http://www.arcgis.com/home/item.html?

id=30e5fe3149c34df1ba922e6f5bbf808f Fig1b: http://www.maps-of-the-world.net/ Large relief map of Israel. Note: The designations employed and the presentation of the material on this map do not imply the expression of any opinion whatsoever on the part of Research Square concerning the legal status of any country, territory, city or area or of its authorities, or concerning the delimitation of its frontiers or boundaries. This map has been provided by the authors. 


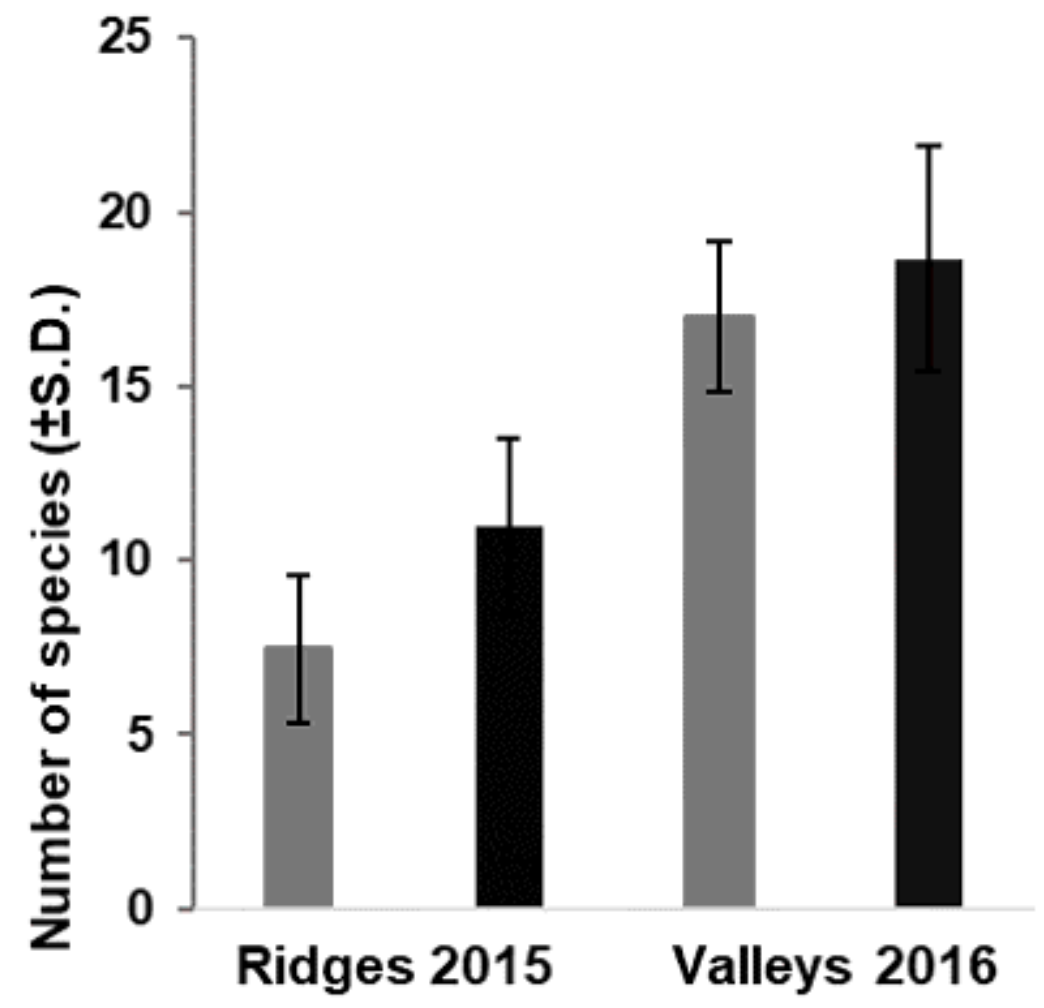

Figure 2

Butterfly species richness in cattle grazing sites (light bars) and in the control sites (ungrazed, dark bars), in two research habitats. Seasonal mean number of species ( \pm S.D.). Significance of difference between managements: ridges (2015), $p=0.0028 *$; valleys (2016), $p=0.17$ * Significant difference $(p<0.05, t-$ test) 


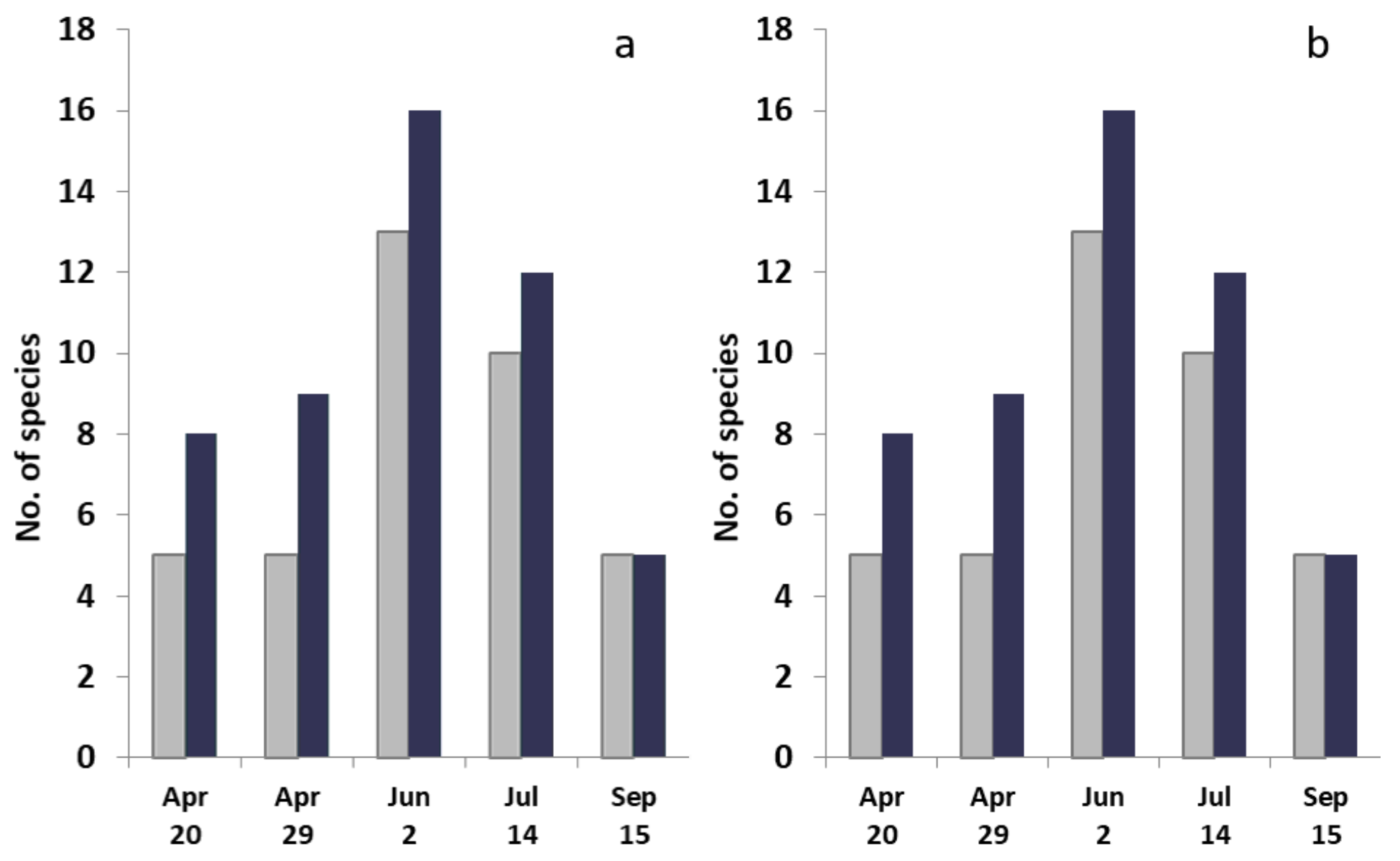

Figure 3

Butterfly species richness along the sampling period, in cattle grazing sites (light bars) and in the control sites (ungrazed, dark bars), in two research habitats. Seasonal mean number of species and significance of difference between managements: a: ridges (2015), grazed -7.6 , control $-10.0, p=0.024 *$; $b$ : valleys (2016), grazed -12.7 , control $-14.0, p=0.10 *$ Significant difference $(p<0.05, t$-test $)$ 


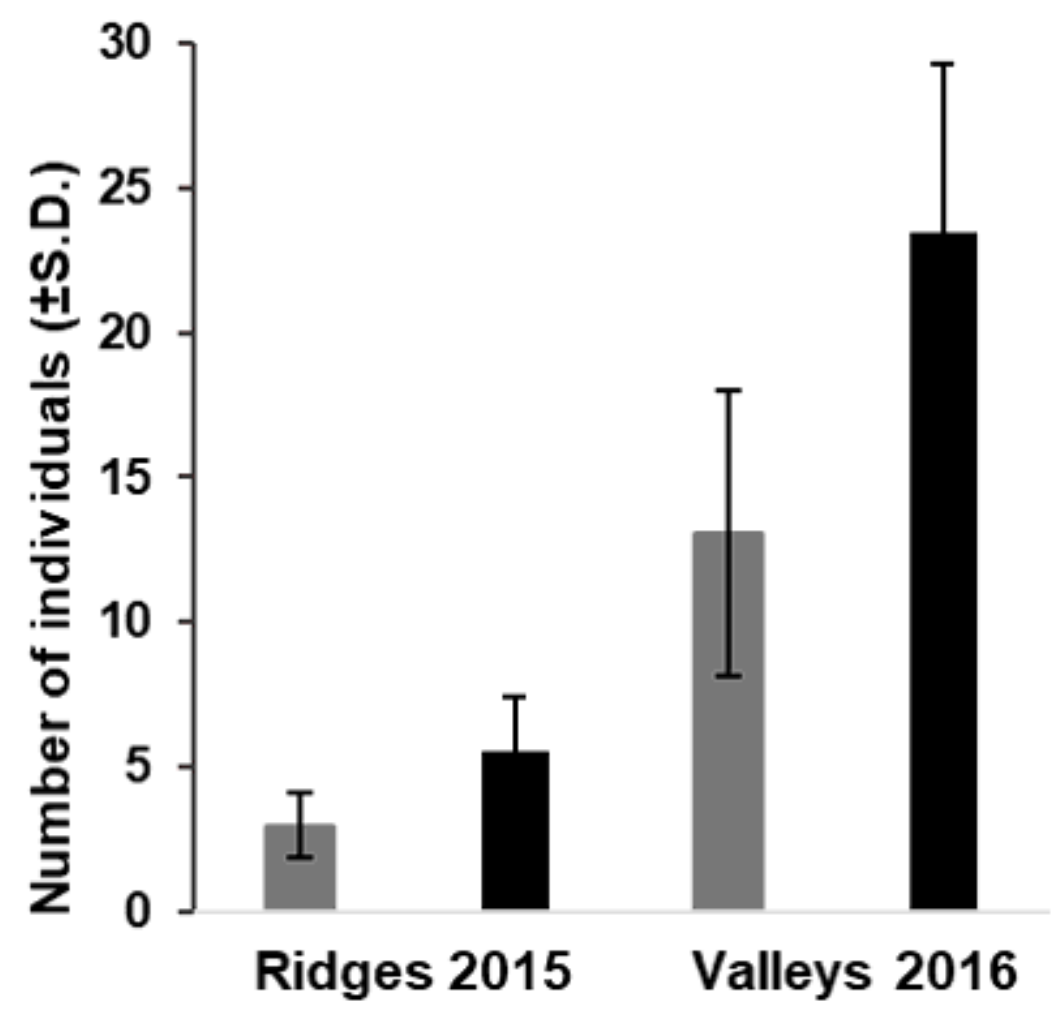

Figure 4

Butterfly abundance in cattle grazing sites (light bars) and in the control sites (ungrazed, dark bars), in two research habitats. Mean number of individuals ( \pm S.D.). Significance of difference between the managements: ridges (2015), $p=0.0015^{*}$; valleys (2016), $p<0.001^{*} *$ Significant difference $(p<0.05, t-$ test) 

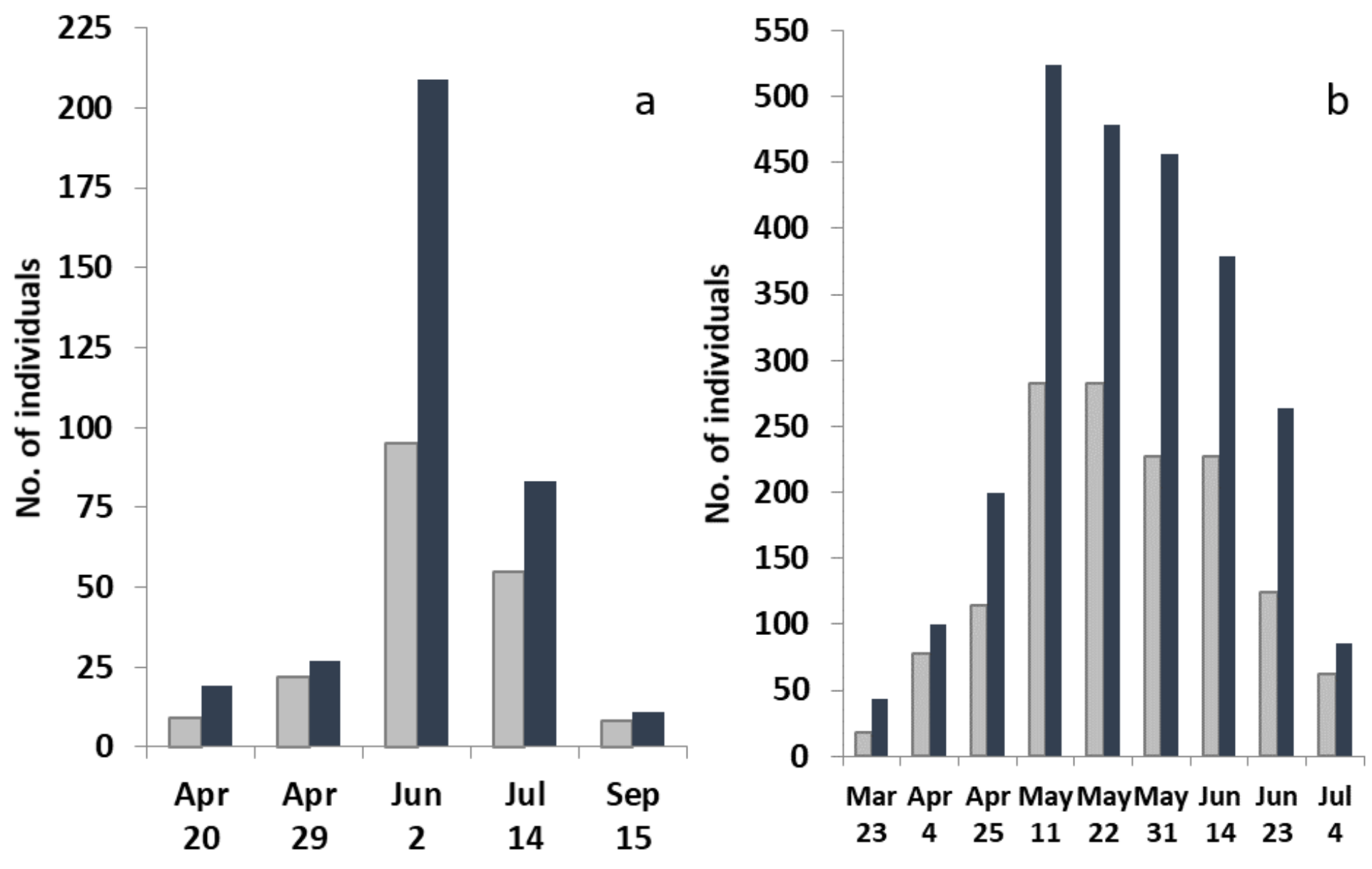

Figure 5

Butterfly abundance along the sampling period, in cattle grazing sites (light bars) and in the control sites (ungrazed, dark bars), in two research habitats. Mean number of individuals and significance of difference between managements: a: ridges (2015), grazed - 37.8, ungrazed $-69.8, p=0.20$; b: valleys (2016), grazed -157.2 , ungrazed $-281.0, p=0.0030 * *$ Significant difference $(p<0.05$, t-test $)$ 


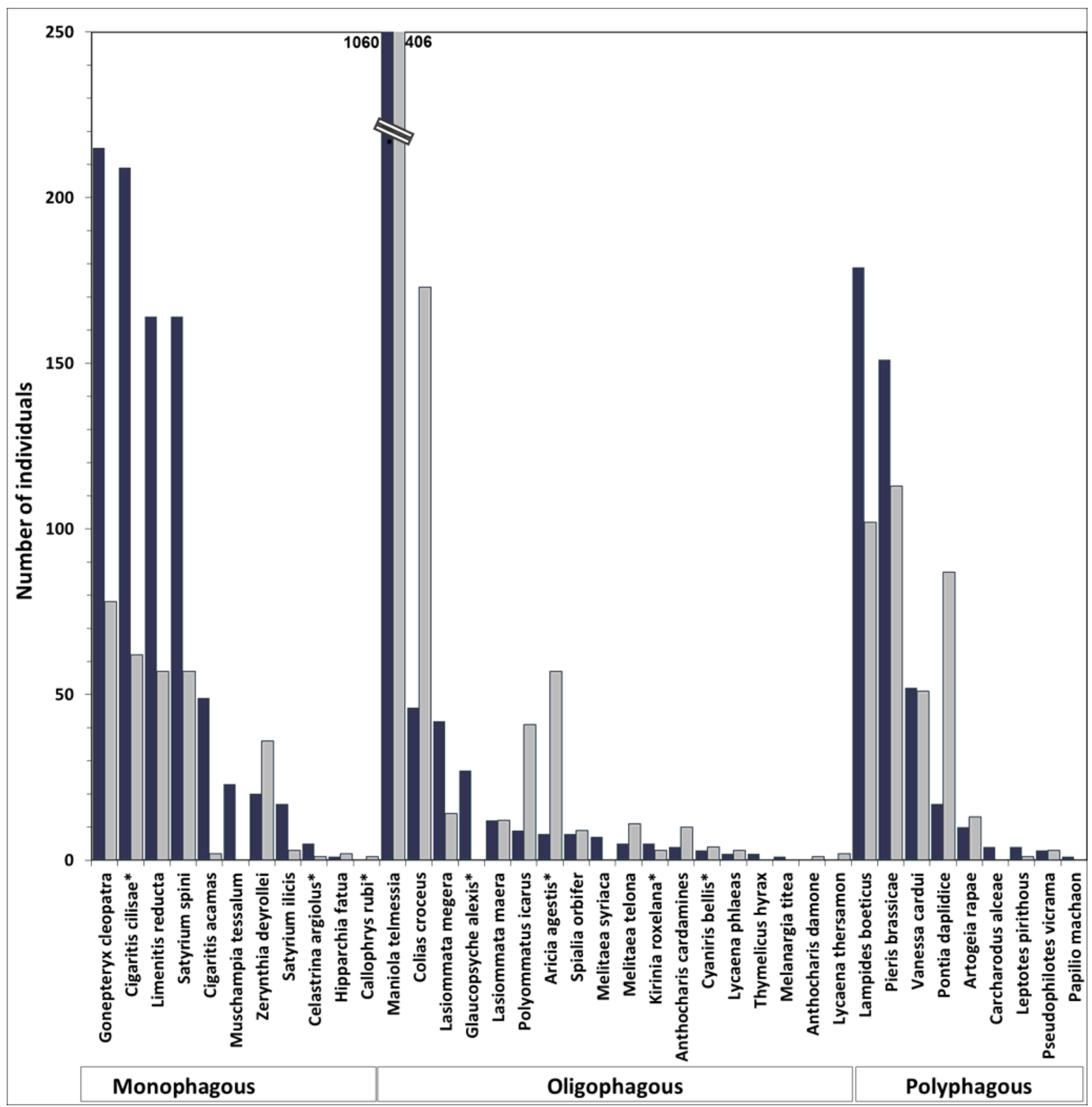

Figure 6

Butterfly abundance in valleys (2016), by feeding strategy, in cattle grazing site (light bars) and in the control site (ungrazed, dark bars). $X$ axis: 38 butterfly species, arranged according to the three feeding strategies (see Table 4). Y axis: accumulation of individual numbers along the research season. Maniola telmessia numbers are out of bounds (marked) 